\title{
Obituary
}

\section{Mr. A. H. S. Lucas}

$\mathrm{A}$ USTRALIAN science loses a notable and versatile votary by the death of Arthur Henry Shakespeare Lucas, on June 9. The son of the Rev. S. Lucas, he was born in 1853 at Stratfordon-Avon and educated at Kingswood School, Bath, and the University of Oxford, where he was an exhibitioner of Balliol College.

Going to Australia as mathematics and science master of Wesley College, Melbourne, in 1883, Lucas later became tutor and natural science lecturer at Trinity, Ormond and Queen's Colleges of the University of Melbourne. From 1893 until 1898 he was headmaster of Newington College, Sydney, after which he joined the Sydney Grammar School as mathematics and science master, and headmaster in 1920. He was also for some time lecturer in physiography at the University of Sydney. Retiring from school work at the end of 1923, he acted for two years as professor of mathematics at the University of Tasmania.

One of the founders of both the Victorian and the New South Wales Naturalists' Societies, Lucas was president of both at different times. In 1907-9 he was president of the Linnean Society of New South Wales, and he was a councillor until his death. For many years he was curator of the Algæ of the Sydney Botanic Gardens, and the last twelve years of his life was devoted to active research and wide collecting of Algæ, from Western Australia to the Barrier Reef, usually spending the summer months-including the last-with his co-adjutors, Mr. and Mrs. Perrin, near Georgetown, Tasmania, in this work. His last paper, "The Marine Algæ of Lord Howe Island", was read at the Linnean Society of New South Wales in June 1935. His "Introduction to Botany", written in conjunction with Prof. Dendy, is a well-known textbook to Australian students. But botany, although his chief love, was but one of many studies. In his teaching life, one learned that his personal pupils in the Senior Public Examinations had won University medals in eleven different subjects--these including all branches of science and mathematics. Besides papers on Australian lizards, in collaboration with the late Dudley Le Souef, he published two books on the animals and on the birds of Australia respectively.

Lucas's passion for acquiring learning led him also into the study of languages. A sound classic and English scholar, he extended his range of modern languages beyond the usual French and German to Italian, Spanish and Russian, by way of holiday pastime. The present writer, spending a summer vacation with him at Twofold Bay, found him reading "Don Quixote" in the original, while during the Great War he was requisitioned to interpret Russian in a law court, in the cause of some Russian refugees. Italian was a necessary concomitant to the study of
De Toni's work on Algæ. Far beyond Dr. Johnson's conception of learning, Lucas earned the famous epitaph on Goldsmith "Nihil quod non tetigit ; nihil tetigit quod non ornavit".

A great teacher, a humorous and lovable friend, Lucas's wide influence was attested by the large and representative gathering which-at the shortest notice-attended Roseville Church to pay the last honours to a rare personality. $\mathrm{He}$ leaves three daughters and three grandchildren. H. J. C.

\section{Dr. J. D. Unwin}

We regret to record the death of Dr. J. D. Unwin, anthropologist and head of Cambridge House, the University social settlement in south London, which took place after an operation at the age of forty years.

Joseph Daniel Unwin was born on December 6, 1895, the son of Mr. F. D. Unwin of Chauntry House, Haverhill, Suffolk. He was educated at Shrewsbury School, and would have gone to Oriel College, Oxford, with a classical exhibition in 1914, had it not been for the outbreak of war. He served in the Northamptonshire Regiment and the Tank Corps, was twice wounded, and was awarded the Military Cross. After the War, he spent some years in Abyssinia. In 1928 he was elected a Fellow Commoner Research Student of Peterhouse, Cambridge. He then compiled a thesis in anthropology for the Ph.D., which was published in abbreviated form in 1933 under the title "Sexual Regulations and Cultural Behaviour". A fuller account of his research, with much additional material, was published as "Sex and Culture" in 1935. His theories of the relation of degrees or stages of culture and the intensity of sexual prohibitions, which was based upon evidence from no less than eighty tribes and peoples, attracted considerable attention and discussion. This book showed that Dr. Unwin had remarkable powers of analysing and marshalling cultural evidence. He had also engaged in research work for the Home Office on the subject of the imprisonment of debtors. 'The results of this research appeared in "Imprisonment for Debt" (1935). He also wrote "Notes on the Unwin Family" (1934).

Dr. Unwin's knowledge of social conditions and problems made his appointment as head of Cambridge House peculiarly suitable; and it was fully justified by his work for the settlement.

\section{Miss Alice Balfour}

Miss Alioe Blanche Balfour, of Whittingehame, who died on June 12, at the age of eighty-six years, was a naturalist born and bred, and her scientific interest in Nature persisted in spite of the social 